\title{
IMPLEMENTAÇÃO DO BIM NO ENSINO DO URBANISMO PARA A ENGENHARIA
}

Modalidade: Experiência de ensino-aprendizagem BIM realizadas

\section{DESENVOLVIMENTO}

A disciplina de Urbanismo do Curso de Engenharia Civil do CEUN-IMT possui carga horária de 80 horas em regime anual de oferecimento. A abordagem histórica anterior foi substituída por leituras temáticas e morfológicas da cidade: água, circulação, moradia e trabalho. Os exercícios práticos passaram a utilizar o Google Earth Pro voltado à análise da forma das cidades em função da água, da circulação e da moradia. As ferramentas legais são apresentadas atualmente de forma contextualizada e a partir de "cases" e problemas que ilustram de forma concreta os instrumentos urbanísticos da cidade de São Paulo.

Figura 1: Etapas do desenvolvimento

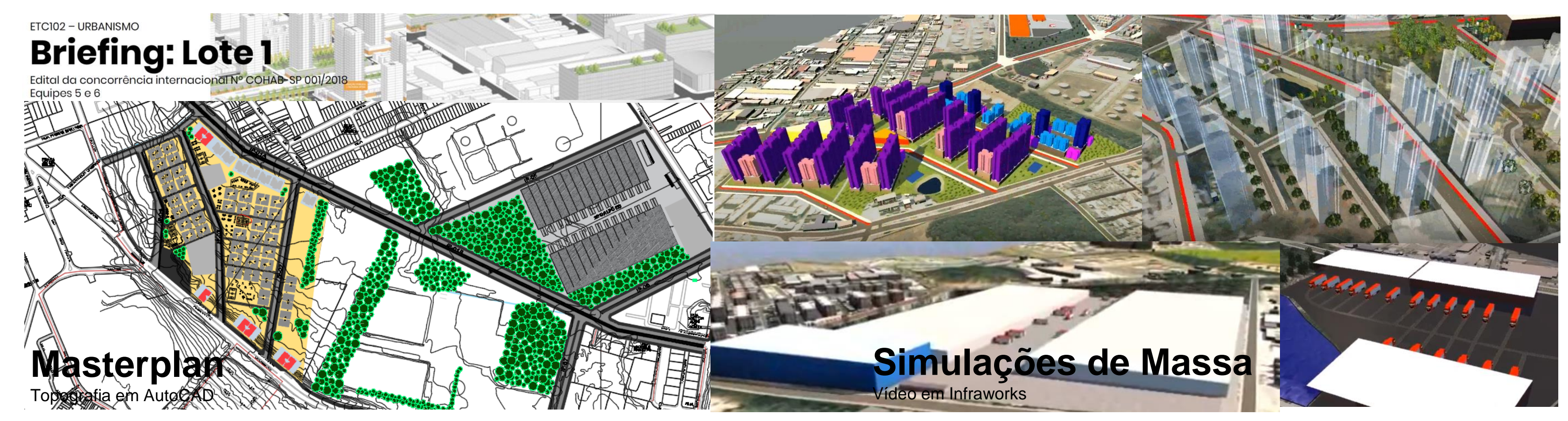

\section{LIÇÕES APRENDIDAS}

Passar do desenho de vias e lotes para 0 desenvolvimento de possibilidades de ocupação em glebas utilizando instrumentos legais e ferramentas urbanísticas representou um ganho para a disciplina. A própria disciplina concebia a cidade em duas dimensões ao utilizar apenas o desenho em Autocad. A utilização do Revit não fez muito sentido, faltava uma etapa de estudo da topografia em Autocad e também uma primeira etapa de concepção que permitisse alterações rápidas. A modelagem precisa do Revit não atendia a necessidade de
Logo após a finalização das análises temáticas, inicia-se o desenvolvimento de propostas para uma gleba urbana, objeto de edital público para a construção de habitações, equipamentos públicos, edifícios mistos, áreas verdes, galpões logísticos dentre outros. Tentativas anteriores incluíram: modelagem em REVIT e modelagem direta no Infraworks. A experiência de 2020 mostrou-se mais adequada ao estudo de viabilidade do empreendimento, quantificação e posterior estudo de massas: setorização inicial em Autocad , massas no Revit e modelagem no Infraworks.

1- CEUN-IMT, pkatakura@maua.br

\section{INTRODUÇÃO}

Diferentes alterações foram pensadas para a disciplina de Urbanismo do Curso de Engenharia Civil do CEUN-IMT desde 2017. Sua estrutura tradicional estava dividida em conhecimentos históricos, instrumentos legais e desenvolvimento de projeto de loteamento. $0 \mathrm{~s}$ loteamentos eram desenvolvidos em Autocad e Revit e ficavam restritos à distribuição de lotes ao longo de vias projetadas. A partir de uma avaliação a respeito das competências a serem adquiridas pelos engenheiros civis para trabalhar em equipes multidisciplinares na área do urbanismo e do planejamento urbano foram realizadas sucessivas alterações até a estruturação de novas linhas de abordagem e metodologias que incorporam ferramentas BIM no ensino. A escolha dos softwares mais adequados a cada etapa é importante fator para o sucesso da disciplina. Egressos do curso não serão responsáveis diretos pelo desenvolvimento de propostas urbanísticas mas devem conhecer os instrumentos urbanísticos $\mathrm{e}$ seus impactos na forma urbana. É com este objetivo que a disciplina passou a centrar seus esforços na aplicação prática das regras urbanísticas nos modelos dos exercícios práticos. 